\title{
HOMOSEXUAL CRIME TOWARDS CHILDREN IN BENGKULU PROVINCE VIEWED FROM ISLAMIC LAW PERSPECTIVE
}

\author{
By : \\ Muhammad Bayu Masifa Asbei, M. Darudin, Sirman Dahwal
}

\begin{abstract}
Homosexual crime behavior on children in Bengkulu province experiences increase every year. Viewed from various religions officially recognized by the state, homosexual behavior categorized as acts that are in contrast to religious values, and Islam condemns such acts. From this background, the problems to be investigated can be formulated as follow: (1) what were the factors causing the occurrence of homosexual crimes on children in Bengkulu province?; (2) what were the criminal sanctions that can be imposed on the subjects of homosexual crimes against children in terms of Islamic law?. To answer these problems, it was used empirical juridical research method. The type of this research was descriptive. Data sources used were primary and secondary data. Data processing was done by editing method, then a qualitative analysis was performed by using the inductive-deductive method. The results showed that (1) the occurrence of homosexual crime on children was caused by factors of: social environment, pornography, and lack of family communication. (2) there were three opinions of fiqh scholars in determining criminal sanctions that can be imposed on homosexual offenders: the first opinion statesthat homosexual offenders shall be sentenced to death; the second opinionstipulates that homosexual offenders are sentenced as adultery. If he is a bikr (unmarried man) then his sentence is to be flogged and exiled from his country. While those who are muhsan (had been married), then he is punished by stoning. The third opinion stipulates that homosexual perpetrators must be given legal sanctions in the form of $t a^{\prime} z i r$, that is a kind of punishment which is aimed at educative and preventive in which the severity is determined by the judge. This Islamic criminal sanctions are heavier than positive law, so they can create a deterrent effect, and reduce the number of sexual crimes on children.
\end{abstract}

\section{Keywords : Homosexual, Children, Islamic Law}




\section{A. INTRODUCTION}

\section{Research Background}

Homosexuality has been labeled as dirty and immoral practices by religion, but later turned into humane practices and must be respected as part of respect for Human Rights. Islam recognizes that humans have a great desire to carry out sex. For this reason, Islam, through laws based on the AlQuran and Hadith, regulates the distribution of biological needs through marriage. Through marriage, human nature can be well maintained, because marriage regulates sexual relationship between men and women with legitimate ties in the form of monogamy and polygamy. The purpose of a marriage for religious people must be as a means to avoid bad deeds and to them keep away from sin. ${ }^{1}$

This can happen, for example, because of jealousy caused by a partner exchange, or other causes. And some impingement occurs in minors, minors are actually the members of the community who are classified as weak both physically and in fulfilling their rights. Therefore, children must be protected and cared for properly. Because children are the next generation and the hope of the nation in

\footnotetext{
${ }^{1}$ Sirman Dahwal, Perbandingan Hukum Perkawinan, Bandung : Mandar Maju, 2017.p. 16
}

the future, in accordance with Law No. 35 of 2014 concerning Children Protection which is explicitly stated that children are the next generation of the nation whose protection must be guaranteed from all forms of violence and discrimination.

In reality, there are still many children who are exploited and become victims of violence acts. According to Law No. 35 of 2014 concerning Children Protection, violence is any act against a child that results in the physical, psychological, sexual and/or negligence pain or suffering, including threats to commit acts, coercion or deprivation of liberty unlawfully. Case of violence against children in Indonesia from year to year continues to increase. According to the KPAI Secretary General stated that the majority of victims of sexual violence were female with a percentage ratio of $60 \%$ male and $40 \%$ female. As happened in the case of the Jakarta International School (JIS) by a janitor, AndriSobari alias Emon, who had committed homosexuals practices on more than 100 children aged 4to 14 years in the public washing room in his village. The case that was strongly highlighted at the beginning of 2016 was the case of artist Saiful Jamil who 
sexually abused a minor. ${ }^{2}$

All victims of homosexual pedophilia will experience psychological problems as a result of the events they experienced, in the form of changes in behavior and emotions such as becoming aggressive, irritable, quiet, or shut down, do not want to go to school, afraid of meeting strangers or afraid to meet people with physical resemblance to the pedophile who commit the harassment. ${ }^{3}$ In addition, children will also experience a regression or setback. Another thing that might happen is children can experience sexually transmitted diseases. Cognitively, the children's thought patterns about marriage or the opposite sex will be disturbed, they will have insecure senses toward the opposite sex. The long-term impact of the incident is that the child will experience trauma, depression or sexual deviation in the future, one of which is that the child might become a pedophile.

Since the average homosexual pedophile perpetrators had experienced violence or sexual harassment when

\section{${ }^{2}$ http:}

//.blogspot.uns.co.id/2014/4/kekerasan-sekslterhadap-anakstudianakdampak-dan-pengaruhnyapdf. Accessed on December 17, 2019.

${ }^{3}$ see https: // media. neliti.com/media / publications / 98530-ID-sexual orientation-factor views -seksual.pdf, Accessed on December 9, 2019, at 07:30 p.m. they are a little, so the children of victims of homosexual pedophilia must get psychological recovery. From the explanation of the case above, it can be seen that the deviant behavior committed by homosexual pedophilia subjects, in fact caused by childhood trauma of being the victim of sexual violence, therefore in adulthood, they have a tendency to do the same thing. Therefore, it is strongly necessary to do proper handling of victims of pedophilia so that it will break the chain of acts of pedophilia violence. ${ }^{4}$

Even though Islam has regulated a legal and legitimate biological relationship, deviations can still occur, whether in the form of adultery or homosexual offenses. And Islamic law needs to be actualized in the civilization of human society, so that Islamic law will be felt and seen in institutions that are both physical and non-physical forms. ${ }^{5}$ The sex instinct itself is the most powerful instinct, which demands distribution. If distribution cannot be satisfying, then people will experience shock and loss of control to control their lust, and sexual intercourse arises outside the rule of law, such as

\footnotetext{
${ }^{4}$ Arif Gosita, MasalahPerlindunganAnak, (Jakarta: Akademika Pressido, 198), p. 32

${ }^{5}$ Akhmad Muslih, AktualisasiSyari'at Islam SecaraKomprehensifDalamPeradabanManusia, (Bengkulu: Kirana, 2004), p. 1
} 
homosexuals due to biological impulses that are not well controlled, caused by lack of understanding and practicing religious teachings. Therefore this study aimed to find out how homosexual crimes against children in Bengkulu province were viewed from the views of Islamic law.

\section{Identification of Problems}

Based on the background described above, the problems in this study were:

1. What were the factors causing the occurrence of homosexual crimes by sexual crimes offenders on children in Bengkulu province?

2. What were the criminal sanctions that can be imposed onhomosexual crimes offenders against children in terms of Islamic law?

\section{B. RESEARCH METHODS}

\section{Research Type}

Legal research generally has a normative juridical type and an empirical juridical type. ${ }^{6}$ This legal research used an empirical juridical approach.

An empirical juridical approach is an approach by looking at legal realities in society, looking at legal aspects in social

${ }^{6}$ Zainudin Ali, Metode Penelitian Hukum, (Jakarta: PT SinarGrafika), 2014, p. 105 interactions within the community, and functions as a support to identify, and clarify the findings of non-legal material for the purposes of research or legal writing. ${ }^{7}$

\section{Research Design}

This research was categorized as descriptive research.

Descriptive research is a research that aims to describe something in a particular area, and at a certain time. Usually in this study, researchers have gotten or obtained a picture which is preliminary data about the problem to be studied. ${ }^{8}$

This research intended to describe or to give a detailed picture of the legal protection of children victims of homosexual crime from the perspective of Islamic law.

\section{Research Location}

The research location in this study was in Bengkulu Province.

\section{Population and Samples}

\section{a. Population}

Population is a whole or a set of objects with the same characteristics. Population can be a

\footnotetext{
${ }^{7}$ Ibid, p. 105

${ }^{8}$ BambangWaluyo, Penelitian Hukum Dalam Praktik, (Jakarta: SinarGrafika), 2008, p. 8
} 
collection of people, objects (living or dead), events, cases, time or place, with the same natures or characteristics. ${ }^{9}$ The population in this study were all homosexual pedophilia crime perpetrators in Bengkulu Province, parents/guardians of children victims of homosexual pedophilia crimes in Bengkulu city, law enforcement officers in the Bengkulu Province area, and Islamic religious leaders in Bengkulu Province consisting of the Indonesian Religious Scholars Council (known as MUI in Indonesian abbreviation), Lecturers of Islamic Law from IAIN Bengkulu, NahdatulUlama (NU), and Muhammadiyah in Bengkulu Province.

\section{b. Samples}

Samples are subsets of or part of the population. ${ }^{10}$ In a study, observations were generally made not to the population, but rather to samples. Sample selection in this study was done by using purposive or judgmental sampling techniques. Purposive or judgmental sampling technique is a technique to determine the sample based on consideration or

${ }^{9}$ Bambang Sunggono, Metodologi Penelitian Hukum, PT Raja Grafindo Persada, Jakarta, 2015, p. 118.

${ }^{10}$ Ibid, p. 119. subjective research from the researcher, so in this case the researcher himself determines which respondent is considered to represent the population. ${ }^{11}$

Based on the description above, the samples in this study were:

1. 3 Perpetrators of homosexual pedophilia in Bengkulu Province

2. 3 Parents/guardians of children victims of homosexual pedophilia crime in Bengkulu Province

3. 3 Bengkulu Regional Police PPA investigators

4. 4 Prominent Islamic Figures in Bengkulu City, consisting of:

a. 1 person from Bengkulu MUI;

b. 1 Lecturer of Islamic Law from IAIN Bengkulu;

c. 1 NahdatulUlama (NU) figure; and

d. 1 Muhammadiyah figure.

\section{Data Sources}

Data sources are the subjects where the data can be obtained. ${ }^{12}$ Data

\footnotetext{
${ }^{11}$ Burhan Ashofa, Metode Penelitian Hukum, (Jakarta: PT Rinneka Cipta, 2007), p. 91.

${ }^{12}$ Suhaimi Arikunto, Prosedur Penelitian Suatu Pendekatan Praktik, (Jakarta: PT Rinneka Cipta), p. 172.
} 
sources in this study consisted of primary data and secondary data.

\section{a. Primary data}

Primary data is the data obtained directly from the first source, namely the behavior of citizens, through research. ${ }^{13}$ The purpose of collecting primary data is to obtain data in the form of information or description about homosexual crimes against children in Bengkulu Province viewed from the perspective of Islamic law.

\section{b. Secondary Data}

Secondary data is the data that includes official documents, books, research results in the form of reports, and so on. ${ }^{14}$ The purpose of secondary data collection is to study official documents, books, research results in the form of reports related to research. After the research material has been collected, an analysis was carried out by using an interpretation of legal material. ${ }^{15}$

\section{Data Collection Technique}

\section{a. Primary Data Collection}

\footnotetext{
${ }^{13}$ Soerjono Soekanto, Pengantar Penelitian Hukum, (Jakarta: UI Press), 1986, p. 124.

${ }^{14}$ Amirudin and Zainal Asikin, Pengantar Metode Penelitian Hukum, (Jakarta: PT Raja GrafindoPersada), 2013, p. 30

${ }^{15}$ Akhmad Muslih, Kedudukan Instruksi PresidenNomor 1 Tahun 1991 Tentang Kompilasi Hukum Islam, (Central Java: UNS Press, 2014), p. 29
}

\begin{abstract}
Primary data collection techniques in this study was conducted by using techniques of involvedobservation and in-depth interviews, in detail, namely:
\end{abstract}

\section{1) Involved Observations}

Involved observation is an observation that puts the researcher in the observed social context, perhaps from the beginning he was a member of the group, or perhaps he joined later, after making the decision to make observations. ${ }^{16}$

\section{2) In-depth Interview}

In-depth interview is the process of studying information for research purposes through question and answer method done face to face between the interviewer and the respondent or interviewee, with or without interview guidelines. ${ }^{17}$

$$
\text { In conducting in-depth }
$$

interviews, several key questions are prepared which serve as flexible guidelines, so that the next question is based on the respondent's answer to the previous question.

\section{b. Secondary Data Collection}

Secondary data collection techniques in this study was performed through document studies. Document studies are conducted on legal materials

\footnotetext{
${ }^{16}$ Soerjono Soekanto ..., Op. Cit., P. 208.

${ }^{17}$ Sutopo, Metodelogi Penelitian Kualitatif, (Surakarta: UNS Press, 2006), p.72.
} 
that are relevant to the research problems. In this research, the legal materials are obtained from studying books, journals, research results in the form of reports, as well as data that already exists in certain communities and institutions, which are related to research.

\section{Data Processing Techniques}

The data that has been obtained will then be processed through the following stages:

\section{a. Data Editing}

Data Editingis a data processing technique that is done by checking or examining the data obtained to ensure whether it can be accounted for in accordance with reality. At the editing stage, the data is selected and checked again to find out whether the data is complete or not. At this stage the correction of erroneous data is added, adding, and completing the missing data. ${ }^{18}$

\section{b. Data Coding}

Data Coding, namely marking the data obtained, either in the form of numbering or the use of certain signs or symbols or words that indicate the class or group of data classification by type, and source, with the aim of presenting data perfectly,

\footnotetext{
${ }^{18}$ Ronny Hanitidjo Soemitro, op.cit., P. 64.
}

facilitating the reconstruction and analysis of data. ${ }^{19}$

In this case the data obtained, both primary and secondary data are first edited to get perfect and complete data, the data is given problem codes in the research.

\section{Data Analysis}

"Data analysis (analyzing) is the process of describing data in the form of sentences that are good and right." ${ }^{20}$ The analytical method used in thesis research on homosexual crimes against children in Bengkulu Province viewed from the perspective of Islamic Law was qualitative analysis. Qualitative analysis method is done by inductivedeductive thinking or vice versa.

"The inductive method is done by drawing conclusions from specific data to general data, while the deductive method is done by drawing conclusions from general data to specific data." ${ }^{21}$ After the data were analyzed one by one, they were then arranged systematically, so as to answer the problems presented in the form of a thesis. Analysis of the data in this study, essentially was carried out continuously from the beginning to the end of the

\footnotetext{
${ }^{19}$ M. Abdi, (et al), Panduan Penulisan Tugas Akhir Untuk Sarjana Hukum, (Faculty of Law, Bengkulu University), 2015, p. 46

${ }^{20}$ Ibid, p. 59.

${ }^{21}$ Soerjono Soekanto ..., Op.Cit., P. 5
} 
study. In analyzing this data, the data was organized, that was classified into patterns, themes or categories.

\section{RESULTS AND DISCUSSION}

\section{Factors CausingSomeone to}

\section{Conduct Homosexual Behavior}

a. Association and Social Environment

Social habits and the environment are the biggest factors contributing to this sexual disorder in which one family member does not show affection and the attitude of parents who feel the explanation about sex is a taboo. ${ }^{22}$ In addition, lack of knowledge and understanding of religion is also an internal factor that influences the occurrence of homosexuals. This is because the researcher feels that religious and moral upbringing is very important in shaping the individual's mind and personality. Religious knowledge plays an important role as the most ideal bastion in educating oneself to distinguish between what is good and what is otherwise, haram and halal and others. ${ }^{23}$

b. Pornography

${ }^{22}$ Sri Habsari, BimbingandanKonseling SMA, accessed on November 24, 2019 at 06.08 p.m from http://books.google.com

${ }^{23}$ Noor Azilawati Mohd Sabda, Siri Pemupukan Motivasi Insan, Menghindari Ancaman Seksual, (T. t: Pinang SDN.BHD), Cet.1, 16. Hlm. 32
Pornography is very easy to enter into the life of the perpetrator. This happens because children have eyes and gadgets in their daily lives. If this is not being taken careand directed by parents, then the child will be addicted to pornography and need special handling. In internet shows many video presentations about lesbian and gay deviant sex acts. If children and teens watch them, they will be addictive and very easily exposed to homosexual behavior.

c. Lack of Communication in the Family

Children and adolescents who have problematic families do not have quality communication and are far from good relationships. Many children and adolescents prefer to be free to tell various things about sexuality. Of course, parents must be aware of the condition of children and adolescents so that parents can be the first and foremost people in directing their growth to avoid homosexual behavior.

d. Hereditary Factors

(Sex

HormoneImbalance)

This factor is commonly called the "gay gene" theory. Magnus Hischeld was the first scientist to introduce this theory in 1899 . He 
asserted that homosexuality is innate so he called for legal equality for all homosexuals. ${ }^{24}$ However, this theory increasingly collapsed when in 1999 Prof. George Rice of the University of Western Ontario, Canada, said there was no link of gene $X$ that was said to be the basis of homosexuality, however the overall results from various studies seemed to indicate that even if there was a genetic link, it was so weak that it became unimportant. ${ }^{25}$

\section{Homosexual Crimes in Children}

\section{According to Islamic Law}

Liwaathis an act that is forbidden by Allah and his messengers. Liwath perpetrators will get damnation from Allah and painful torture. This is based on the warnings given by Allah by referring to his words which tell the story of the people theofProphet LutAs. Many verses in the Qur'an have warned of the wrath of Allah towards the liwaath. ${ }^{26}$ Liwaath is an act of sin that is feared by the Messenger of Allah, which can befall Muslims. Narrated by Imam Ahmad (2915) from Ibn Abbas $R$ a that the Prophet said:

\footnotetext{
${ }^{24}$ Kartini Kartono, Psikologi Abnormal danAbnormalitasSeksual, (Bandung: CV. Mandar Maju, 1989), p. 248.

${ }^{25}$ www.narth.com,Jupiter And, 2002, RuntuhnyaTeori "Gay Gene". accessed on November 24, 2019 at 05.55 p.m.

${ }^{26}$ Asadulloh AI Faruk, Hukum Pidana Dalam Sistem Hukum Islam, (Bogor: Ghalia Indonesia), p. 30-31.
}

Allah curse anyone who acts like the actions of the people of the Prophet Lut. Allah curse anyone who acts like the actions of the people of the Prophet Lut, he conveyed up to three times. (Honored by ShaykhSyu'ib AlArna`uth)

Then the Prophet cursed three times to anyone who did something like what had been done by the people of Lut, namely liwaath (homosexual).

\section{CLOSING}

\section{a. Conclusion}

Based on the results of empirical juridical research on homosexual crimes toward children in Bengkulu Province, it can be concluded that: (1) there were several factors causing homosexual crime on children: social environment, pornography, lack of family communication, and hereditary factors in the form of sex hormone imbalances.; (2) there were three opinions of fiqh scholars in determining criminal sanctions that can be imposed on homosexual offenders: the first opinion states that homosexual offenders shall be sentenced to death; the second opinion stipulates that homosexual offenders are sentenced as adultery. If he is a bikr (unmarried man) then his sentence is to be flogged and exiled from his country. While those 
who are muhsan (had been married), then he is punished by stoning. The third opinion stipulates that homosexual perpetrators must be given legal sanctions in the form of Ta'zir.

\section{b. Suggestion}

The implementation of Islamic law will indeed get certain difficulties in today life, because those who realize the wisdom of Islamic law are only a small portion of Muslims, especially intellectuals and scholars. If all levels of society realize the importance of Islamic law in managing life then it can be applied in all aspects of life.

\section{Bibliography}

Abu Ameenah Philips dan Zafar Khan, Islam dan Homoseksual, Jakarta : Pustaka Zahra, 2003).

Akhmad Muslih, Aktualisasi Syari'at Islam Secara Komrehensif Dalam Peradaban Manusia, Bengkulu : Kirana, 2000.

Kapita Selekta dan Dinamika Hukum Islam, Jakarta : Katalog Dalam Terbitan, 2007.

, Kedudukan Instruksi Presiden Nomor 1 Tahun 1991 Tentang Kompilasi Hukum Islam, Jawa Tengah : UNSPress, 2014.

Amirudin dan Zainal Asikin, Pengantar Metode Penelitian Hukum, Jakarta : PT Raja Grafindo Persada.
Arif Gosita, Masalah Perlindungan Anak, Jakarta: Akademika Pressido, 1998.

Asadulloh AI Faruk, Hukum Pidana Dalam Sistem Hukum Islam, Bogor: Ghalia Indonesia.

Bambang Sunggono, Metodologi Penelitian Hukum, PT Raja Grafindo Persada, Jakarta, 2015.

Bambang Waluyo, Penelitian Hukum Dalam Praktik, Jakarta : Sinar Grafika, 2008.

Burhan Ashofa, Metode Penelitian Hukum, Jakarta: PT Rinneka Cipta, 2007.

Kartini Kartono, Psikologi Abnormal dan Abnormalitas Seksual, Bandung : CV. Mandar Maju, 1989,

M. Abdi, (et al), Panduan Penulisan Tugas Akhir Untuk Sarjana Hukum, Fakultas Hukum Universitas Bengkulu, 2015.

Mohammad Darudin, Reprroduksi bayi tabung, ditinjau dari Hukum Kedokteran, Hukum Perdata, Hukum Islam, Jakarta : Radar Jaya, 1997.

Noor Azilawati Mohd Sabda, Siri Pemupukan Motivasi Insan, Menghindari Ancaman Seksual, (T. t: Pinang SDN.BHD), Cet.1, 16

Sirman Dahwal, Hukum Perkawinan Beda Agama Dalam Teori Dan Praktiknya Di Indonesia, Bandung : Mandar Maju, 2016.

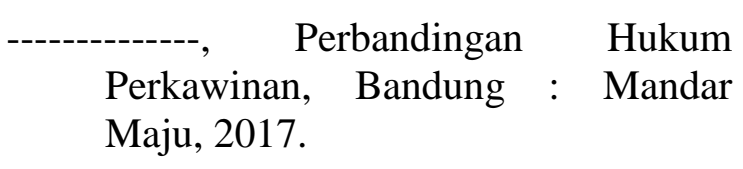

Soerjono Soekanto, Pengantar Penelitian Hukum, Jakarta : UI Press, 1986. 
Suhaimi Arikunto, Prosedur Penelitian Suatu Pendekatan Praktik, Jakarta : PT Rinneka Cipta.

Sutopo, Metodelogi Penelitian Kualitaif, Surakarta : UNS Press, 2006.

Zainudin Ali, Metode Penelitian Hukum, Jakarta : PT Sinar Grafika, 2014. 